\title{
THE USE OF THE RENZULLI-HARTMANN RATING SCALES (2010) WITH ITALIAN TEACHERS PRELIMINARY DATA FROM A CORRELATION ANALYSIS
}

\author{
Clarissa Sorrentino \\ Department of History, Society and Human Studies, University of Salento (Italy)
}

\begin{abstract}
The assessment of Gifted students represents a new emergent area of study in Italy. Education and training programs start from a good evaluation of children' potential and their learning characteristics (Tomlinson, 2012). The lack of appropriate identification procedures often does not allow teachers to understand the student's needs of exploration and knowledge. Consequently, it usually happens that Gifted students underachieve (Neihart \& Betts, 2010) and/or do not receive appropriate instructional and educational supports. In continuity with this need of useful instrument of observations for teachers, this study presents the results of part of a macro-study for the adaptation of the Renzulli-Hartmann Rating Scale (2010) in the Evaluation of Giftedness in Italian middle schools in south-eastern, north and centre Italy. Considering the different educational panorama in terms of inclusive practices of Italy and America the study will primarily present the inclusive historical pathway in the American and Italian school system. Successively, the contribute will present the analysis of the correlation between the learning subscale chosen from the Renzulli-Hartmann Rating Scale (2010) and the final marks of 140 students of second and third year of a middle school. These preliminary data will be helpful to understand if the instrument presents a strong concurrent validity and it is relevant to the Italian context.
\end{abstract}

Keywords: Giftedness, assessment, school, teachers, Renzulli.

\section{Introduction}

In the educational and psychological literature there are different conceptions of intellectual giftedness. It is described as a general cognitive ability, often identifying it with a high IQ, or a domain-specific characteristic. Some systemic models offer a more systematic vision and describe giftedness as the union of several cognitive and non-cognitive variables. These models have influenced not only the ideas of teachers and educators on giftedness, but also their educational practices. The systemic models have overcome this classical conception going to detect other psychological variables in the definition of the construct. According to the systemic models, giftedness is given from the confluence of psychological processes that work together, processes that are not only cognitive but also emotional and relational (Kaufmann \& Sternberg, 2008, p.76). Parents, teachers and even peers can contribute significantly to the balance of this elements and to the expression of a specific talent (Monks \& Boxtel, 1985). As regard school provisions and support for gifted students we can assist to more and less inclusive practices. In the USA gifted students assist regular classroom and schools usually offer them special programs. According to the US Department of Education around 6\% of US students benefit of those programs (2003). In some states special services for gifted students are regulated by the states special education law (U.S. Department of Education, 2008). The No Child Left Behind Act of 2001 (NCLB), a comprehensive law "designed to improve the educational performance of all students in the U. S. [...] schools must be held accountable for educational outcomes for all students, including those with any type of disabilities" (p.23), stirred controversy among gifted education (Gallagher, 2004) above all because gifted students "have been increasingly passed over at their own expense" (Beisser, 2014, p.11).

In 2005, 11 years after the European Recommendation, a research entitled «Gifted Education in 21 European Countries: Inventory and Perspective », conducted by Professor Franz J. Monks and Robin Pflüger of the Radbound University of Nijmegen (Netherlands) on behalf of the German Ministry of Education and Research, review the educational modalities specifically related to gifted students implemented by 21 countries of European Union. According to this document, in Italy, giftedness was ignored within the national school system. 
Although in Italy there is no specific legislation that intervenes in matter of Giftedness with the exception of a regional provision of $2012^{1}$ the regulations regarding school autonomy ${ }^{2}$ and the protection of special educational needs ${ }^{3}$ (Ministerial Directive 2012) allow the school to decide in educational and organizational terms how to respond to these new requests (Pinnelli, 2017).

In Italy gifted students attend regular classrooms and could receive specific enrichment programs in specific school subjects; they could benefit of curriculum compacting, mentoring, extra-curricular programs and web courses. They could also skip the classroom only once in their school career students can access in advance both primary and secondary schools (Roncoroni, 2017).

Going back to the Monks European Report, beyond the lack of an official Legislative Recognition and Regulations, all the documents report, above all, the lack of specific identification criteria and giftedness recognition relies often on parents, teachers and self-nominations.

In order to offer more specific tools for teachers, an Italian validation of the Renzulli-Hartman Scales for Rating the Behavioural Characteristics of Superior Students (Renzulli, et al., 2010) is carried out. In this study only the correlation analysis of one subscale is presented.

\section{Design}

\subsection{Instrument}

In this study teachers judgment measures were used to explore the students' potential. These instruments are in line with the Renzulli's definition of giftedness. Between the three more worldwide used and empirical supported scales: Scales for Rating the Behavioural Characteristics of Superior Students, Scales for Identifying Gifted Students (Ryser \& McConnell, 2004) and Gifted Rating Scales (Pfeiffer \& Jarosewich, 2003) the first are used.

The Italian translation of the Renzulli-Hartman Scales for Rating the Behavioural Characteristics of Superior Students (Renzulli, et al., 2010) was used for this procedure. These rating scales "are not used to eliminate students with lower ratings [but] to provide a composite profile of the nominated students" (Renzulli, Reis, 1997, p. 60). The original SRBCSS-III (revised edition) comprehends a total of 14 scales aimed to evaluate the following areas:

Table 1. Subscales for Rating the Behavioural Characteristics of Superior Students (Renzulli et al., 2010) On the purpose of this study only the learning subscale will be considered.

Learning Characteristics

Creativity Characteristics
Motivation Characteristics
Leadership Characteristics
Artistic Characteristics
Musical Characteristics
Dramatics Characteristics
Communication Characteristics (Precision)
Communication Characteristics (Expressiveness)
Planning Characteristics
Mathematics Characteristics
Reading Characteristics
Technology Characteristics
Science Characteristics

Every single scale of the instrument assesses different aspects of the person, from basic skills to transversal ones. In the learning subscale the teacher assesses the student answering to 11 questions about the learning style of the student (inductive or deductive), their reasoning and memory ability. According to the "Protocol for completing Renzulli Behavioural Rating Scales" the following steps were observed during the administration:

\footnotetext{
${ }^{1}$ Deliberazione della Giunta Regionale del Veneto n. 1192 del 25/06/2012, Approvazione avviso pubblico per la realizzazione di interventi a supporto dei bambini con buon potenziale cognitivo - Potenziare il potenziale nel sistema scolastico.

${ }^{2}$ Regolamento dell'autonomia scolastica di cui al D.P.R. 275/1999.

${ }^{3}$ Legge 170 del 2010, Nuove norme in materia di disturbi specifici di apprendimento in ambito scolastico.
} 
1. Students must be observed from the teacher for a minimum of nine weeks before rating scales can be completed.

2. Identification of two teachers from different academic content areas to complete both the creativity and motivation rating scales.

3. Training of selected teachers on the Renzulli Rating Scale.

4. Teachers complete the Scale for each student after training.

5. Rating scales must be completed independently, never collaboratively.

The students' final marks of the same school year were used to establish the correlation. The final marks consist of an average of the single school subjects' final marks (Italian, math, technology, music, art, history, geography, physical education, science, English, and third language) and the mark on the behaviour.

\subsection{Sample}

The researchers who conducted the study obtained parents approval to conduct the surveys and collect other student information used in this study. Data were gathered from a convenience sample of 9 teachers (three of them had a specialization also in Special educational needs and one was actually working as a SEN teacher). The 9 teachers made 212 evaluations to 140 students (some students were evaluated by two different teachers) attending a village middle school in Eastern South Italy during the 2016-2017 school year. 77 students (55\%) were boys and $63(45 \%)$ were girls. Students were in grades 6 and 7 , corresponding to the Italian first and second year of middle school.

\section{Results}

Before conducting the analysis to compare the results of the two groups, both variables were tested for Normality using Shapiro Wilk normality test (See tables 2 and 3). Because those values are below.05 we assume that the data are not normally distributed and for this reason.

Table 2. Tests of Normality.

\begin{tabular}{|l|r|r|r|r|r|r|}
\hline \multirow{2}{*}{} & \multicolumn{4}{|c|}{ Kolmogorov-Smirnov(a) } & \multicolumn{3}{c|}{ Shapiro-Wilk } \\
\cline { 2 - 7 } & Statistic & df & Sig. & Statistic & \multicolumn{1}{c|}{ df } & \multicolumn{1}{c|}{ Sig. } \\
\hline Marks &, 116 & 210 &, 000 &, 953 & 210 &, 000 \\
\hline
\end{tabular}

a Lilliefors Significance Correction

Table 3. Tests of Normality.

\begin{tabular}{|c|c|c|c|c|c|c|}
\hline & \multicolumn{3}{|c|}{ Kolmogorov-Smirnov(a) } & \multicolumn{3}{|c|}{ Shapiro-Wilk } \\
\hline & Statistic & df & Sig. & Statistic & df & Sig. \\
\hline $\begin{array}{l}\text { LEARNING } \\
\text { subscale }\end{array}$ &, 055 & 210 &, $200(*)$ & ,982 & 210 &, 010 \\
\hline
\end{tabular}

According to the results as the assumptions of Pearson's bivariate Correlation are not met, only Spearman's rho Correlation Analysis can be used in this case. As shown in Table 4, the Renzulli learning subscale was significantly correlated with the students final marks $(r=.809, \mathrm{p}<.01)$.

Table 4. Correlation between the Renzulli learning Subscale and students' final marks.

\begin{tabular}{|lll|r|r|}
\hline & & \multicolumn{1}{|c|}{ Marks } & LEARNING \\
\hline Spearman's rho & Final Marks & Correlation Coefficient & 1,000 &, $809(* *)$ \\
& & Sig. (2-tailed) &. &, 000 \\
& & $\mathrm{~N}$ & 210 & 210 \\
& \multirow{2}{*}{ LEARNING } & Correlation Coefficient &, $809(* *)$ & 1,000 \\
& & Sig. (2-tailed) &, 000 & $\cdot$ \\
& & $\mathrm{N}$ & 210 & 210 \\
\hline
\end{tabular}

** Correlation is significant at the 0.01 level (2-tailed). 


\section{Conclusions}

Giftedness is a multidimensional construct that takes in consideration cognitive and not cognitive factors. For this reason gifted identification is not a linear and univocally defined process. "School information, familiar information and child observations in classroom should be considered together, and each information has the same "dignity" to be considered in a democratic evaluations of the students because they capture aspects of the child in different contexts and situations and, above all else, its inner potential" (Sorrentino, 2019, p.561). As regard school information, specific instruments for teachers are needed in order to find gifted students and to not lose their potential.

In this research we wanted to present part of a broader validation study of the Italian version of the Renzulli Subscale. Although this data is only preliminary and the sample need to be extended with more evaluations, these first results demonstrate a strong concurrent validity of the Renzulli learning subscale with school final marks. Further studies need to be carried out to examine the validity of the whole instrument and its efficacy for Italian teachers.

\section{References}

Beisser, S.R. (2014) Unintended consequences of no child left behind mandates on gifted students. (n.d.) $>$ The Free Library. (2014). Retrieved Mar $14 \quad 2019$ from https://www.thefreelibrary.com/Unintended+consequences+of+no+child+left+behind+mandates+o n+gifted...-a0218606475

Gallagher, James J. (2004). No child left behind and gifted education. Roeper Review, 26:3, 121-123, DOI: $10.1080 / 02783190409554255$

Kaufman S.B., Sternberg R.J. (2008) Conceptions of Giftedness. In: Pfeiffer S.I. (eds) Handbook of Giftedness in Children. Springer, Boston, MA

McLeskey, J., Rosenberg, M. S., \& Westling, D. L. (2009). Inclusion: Effective practice for all students. Upper Saddle River, NJ: Pearson Education, Inc.

Mönks F. J. (1992). Development of gifted children: The issue of identification and programming. In F. J. Mönks, W. A. M. Peters (Eds.), Talent for the future (pp. 191-202). Proceedings of the Ninth World Conference on Gifted and Talented Children. Assen, the Netherlands: Van Gorcum.

Mönks F.J., Boxtel H.W. Van (1985). Gifted adolescents: A developmental perspective. In J. Freeman, (Ed.), The Psychology of Gifted Children. An International Collection of Studies. London: John Wiley \& Sons.

Mönks, F. J. \& Pflüger, R. (2005). Gifted Education in 21 European Countries: Inventory and Perspective. Publisher, Radboud Universiteit.

No Child Left Behind Act, P.L. 107-110. Title IX, Part A, Definitions (22) (2002); 20 U.S.C. Sec. 7802 (22).

Pinnelli, S. (2017). L'educazione inclusiva nel continuum del progetto pedagogico. Integrazione Scolastica e Sociale. Vol. 16, n. 1, Erickson ed. Trento.

Ryser, G. R., \& McConnell, K. (2004). SIGS complete kit: Scales for Identifying Gifted Students [published instrument]. Waco, TX: Prufrock Press. Available from http://www.prufrock.com/productdetails.cfm?PC=212

Sorrentino, C. (2019). Creativity Assessment in School: Reflection from a Middle School Italian Study on Giftedness. Universal Journal of Educational Research, v7 n2 p556-562 2019.

Stephens K.R. (2008). Applicable Federal and State Policy, Law, and Legal Considerations in Gifted Education. In: Pfeiffer S.I. (eds). Handbook of Giftedness in Children. Springer, Boston, MA.

U.S. Department of Education. Office of Special Education and Rehabilitative Services. (2008). Education and Inclusion in the United States: A Brief Overview. Washington, D.C. 